DOI https://doi.org/10.36059/978-966-397-176-6/160-187

\title{
MOTIVATIONAL COMPONENT IN THE SYSTEM OF TRAINING FUTURE SPECIALISTS IN SOCIAL WORK TO PROVIDING SOCIAL SERVICES
}

\section{Cherneta S. Yu., Sushyk N. S.}

\section{INTRODUCTION}

The modern reforming of higher education and field of social services in Ukraine puts forward new requirements such as education, self-critical nature, the ability to think and make informed decisions, initiative, mobility in the labor market, psychological readiness to perform the chosen professional activity for modern specialists. Expanding the field of professional activity of a social worker, intensity of public changes, reforming the system of providing social services, introduction of new social standards and values set conceptually new requirements for the personality of a social worker.

Nowadays, responsibility for the results of their work, the ability to independently acquire the necessary knowledge and creatively apply it in practice are the key conditions for professional and career growth of a young person. Higher professional education is a fundamental and necessary component of a holistic system of continuing professional education in current conditions of fierce competition in the labor market.

Reforming and creating a new market of social services requires a qualitatively new specialist in providing social services. In the current conditions of transformation of society, the institutions of higher education of Ukraine face a difficult, responsible task, which is highquality training of future specialists in the system of higher education for professional activity in specific conditions; providing labor market with qualified specialists; meeting educational needs of the student and helping him in awareness of his mission ${ }^{1}$.

Слозанська, Г. І. Взаємозв'язок професійної підготовки студентів спеціальності «соціальна робота» у ВНЗ з можливістю їхнього працевлаштування. Науковий вісник Ужгородського національного університету. Сер: Педагогіка. Сочіальна робота. Ужгород, 2016. № 39. С. 236-240. 
For providing high-quality training of specialists in social work to providing social services, the cooperation of higher education institutions with institutions of social field, territorial communities. However, if the higher education institutions of Ukraine have experience in training specialists in social work, then, as the author notes, the introduction of positions of social work specialists in the territorial community is at the primary stage, accordingly, the requirements to the professional activity of a social work specialist in providing social services and to his personality have theoretical nature ${ }^{2}$.

In our opinion, it was important to adopt the qualification characteristics of the profession "Specialist in social work" (2020) and "Social Manager" (2021) to fill this gap.

Another problem is that modern conditions of admission to higher education institutions sometimes lead to unconscious and nonindependent choice of profession. Therefore, the forming of professional motivation of specialists in social work is an important factor of its competitiveness in the system of providing social services.

The effectiveness of professional activity depends on the study of the motivational field, since the motivation is the driving force of behavior of a human, what plays a significant role in professional selfdetermination, and is a necessary condition of the forming of individual style of activity, professionally significant qualities. Namely, the motivational component of learning not only provides the high results when pedagogical influence, but also activates the cognitive activity of the students.

\section{Professional motivation in the system of training future specialists in social work}

Purposeful forming of professional motivation contributes to a kind of combination of students with the process and outcomes of learning, directly affects their personal development throughout their learning in institution of higher education and further professional establishment

2 Слозанська, Г.І. Теорія і практика професійної підготовки майбутніх соціальних працівників до роботи у територіальних громадах. Дис. на здобуття наук. ступеня д-ра пед. наук. 13.00.05. Тернопіль. 2019. 687 с. 
through the launch of the mechanism of professional self-determination and self-development.

Therefore, the process of forming professional motivation needs the correction, management and intensification by teachers, parents, heads, employers and society as a whole.

The teaching and educational process in higher education plays the leading role in the professional training of students and the forming of the personalities of future specialists. This is a special form of transfer and assimilation of social and historical experience, which is a complex unity of activities of the scientist-teacher and student that are aimed at achieving a common goal, which is mastering scientific knowledge, skills and abilities by students and various development of future specialists as personalities ${ }^{3}$.

Motivation in the system of professional training is manifested in a kind of system of relations between the personality and the activity: before being included in a certain type of activity (mostly of a cognitive nature), prior psychic preparation in the prospect for inclusion in a completely different type of activity in terms of structure and functions is required. This requires a special ratio of factors: the presence of a prolonged goal, which subordinates the emergence, awareness and realization of current motives; the priority of predicted (at the rational level) remote consequences of actions and deeds over immediate needs and motives. High positive motivation can play the role of a compensatory factor, if the level of development of special abilities or gaps in the necessary knowledge, skills and abilities of the student is not high enough. Such a compensatory dependence is not observed in the opposite direction. This means that none (even the highest) level of intellectual abilities of a student can compensate for his low learning motivation and directly contribute to his successful educational and professional activity. That is why an important problem is the task of forming professional motives for learning, the need to acquire

${ }^{3}$ Хорошайло Ю. Є. Особливості професійної мотивації та ії врахування в роботі 3 персоналом. Актуальні проблеми соціальної, психологічної та виховної роботи в OBC: Матеріали науково-практичної конференції (Харків, 30 жовтня 2008 року). Х.: ХНУВС, 2008. С. 3-4. 
professional knowledge, skills and abilities. Then learning gives pleasure, causes positive feelings, desire to work $^{4}$.

Professional motivation as a property of the personality is a system of goals, needs, which encourage the student to acquire actively knowledge, mastering skills and abilities, a conscious attitude to the profession ${ }^{5}$. Therefore, the purposeful forming of professional motivation in students is one of the priority tasks of the higher education.

As it is noted by E.P. Ilyin ${ }^{6}$, a significant amount of research of the motivation of educational activity bears the imprint of shortcomings in views on motivation and motive.

The experience of modern teachers shows that the professional motivation of students is actively formed in 3-4 courses of learning, when professionally oriented disciplines are studied in depth and practice is carried out.

Scientists allocate some features of the educational activity of a student, in particular:

- the learning of scientific information and gaining practical experience has a professional orientation, that is, it is considered as preparation for future professional activity, performance of important social functions, mastering the necessary knowledge for this, skills and abilities, development of the personality of the specialist;

- the subject of activity of the student is the study of science in its development, mastering the process of forming scientific knowledge and the methods of science itself, acquaintance with its problems, tasks and approaches to their solution, as well as learning the methods of professional activity and the content of the social roles of an adult who works;

- special means of activity (scientific literature, textbooks and teaching manuals, Internet and multimedia tools, laboratory equipment

4 Толмачова I. М. Формування професійної мотивації у майбутніх учителів початкових класів у процесі вивчення педагогіки. Молодий вчений. 2015. № 11 (26). Ч. 3. С. $64-67$.

5 Бірюк О.О. Психологічні особливості професійної мотивації педагогічних працівників загальноосвітніх навчальних закладів нового типу : автореф. дис. на здобуття наук. ступеня канд. психол. наук : спеціальність 19.00.10 «Організаційна психологія; економічна психологія». Київ, 2012.

${ }^{6}$ Ильин Э.П. Психология для педагогов. Питер, 2012. 638 с. 
and technical means of training, real and theoretical models of future professional activity, communication with peers, teachers and representatives of the profession);

- the activity of the student takes place in pre-planned conditions (limited period of study and clear schedule of the educational process, content of educational activity is determined by curricula and programs, the identity of the regime of operation of institution of higher education, etc.);

- specific weight of independent work significantly increases in the study of student (independent search for educational information, annotation and taking notes of scientific literature, performance of practical tasks, implementation of professional functions during the internship, carrying out research, etc.);

- the combination of educational and scientific processes, independent educational and cognitive activity of students takes place in parallel with their research work (course works, theses, master's theses) under the leadership of teachers;

- learning in higher education is a complex and difficult process that requires a high level of consciousness and activity, extremely high intellectual tension, concentration, attention, mobilization of willpower and increasing productivity, self-organization, rational distribution of time for study and rest from the student ${ }^{7}$.

A.K. Dustavytskyi considers that namely theoretical (i.e. aimed at cognition of the way of existence of an object or phenomenon, the principle of its explanation). If such interests are absent, or they are underdeveloped, the educational activity of the student is governed by other motives: the desire to obtain higher education in general (i.e. a diploma). Then we can say that there is no psychological basis of the deployment of full-fledged educational and professional activity ${ }^{8}$.

There are three points of view regarding the effectiveness of professional training in the institution of higher education: 1) the dominance of professional motives, which are external regarding the educational process, leads to the decrease of results in cognitive activity;

\footnotetext{
${ }^{7}$ Ляшенко І.В. Формування професійної мотивації студентів до успішної фахової діяльності. URL : www.narodnaosvita.kiev.ua/?page_id=1076

8 Дусавицкий А.К. Мотивы учебной деятельности студентов. Учеб. пособие. Харьков: ХГУ, 1987. 55 с.
} 
2) professional motives in comparison with cognitive ones, more intensively influence the efficiency of educational activity of students, therefore it is desirable that professional ones were leading in the hierarchy of motives of students; 3) cognitive and professional motives are closely related among themselves and increase the productivity of the educational process ${ }^{9}$.

I.A. Zymnia, researching problems in the motivation, allocates two types of the motivation: external (externally motivated behavior) and internal (intrinsically motivated behavior) ${ }^{10}$. According to the scientist, educational activity is generated primarily by the internal motive, when the cognitive need finds its reflection in the subject of activity. Intellectual and cognitive motives, which are understood by human as the desire to acquire knowledge, expand the worldview, systematization of knowledge are very important for educational activity. At the same time, educational activity is influenced by various external motives: selfaffirmation, prestige, responsibilities, achievement. The motive of achievement plays an important role in satisfaction with educational activity, since this motive increases the social activity of students and forces them to concentrate more on learning ${ }^{11}$.

In addition, learning motivation is characterized by a complex structure, systematic, direction, dynamism, sustainability and is associated with the level of intellectual development and the nature of learning activity.

Agreeing with the above opinions, A.K. Markova rightly notes: "The motivation of learning consists of a number of motivations (needs, content of teaching for the student, motives of teaching, goals, emotions, interests), which are constantly changing and entering into new relationships with each other. Therefore, the establishment of motivation is not a simple growing of positive or increasing of negative attitude to

9 Дусавицкий А.К. Мотивы учебной деятельности студентов. Учеб. пособие. Харьков: ХГУ, 1987. 55 с.

${ }^{10}$ Кочарян О. С., Фролова С. В., Павленко В. М. Структура мотивації навчальної діяльності студентів. Навч. посіб. Харків : Нац. аерокосм. ун-т ім. М. Є. Жуковського «Харк. авіац. ін-т», 2011. 40 с.

11 Гузь Н.В. Вивчення мотивів учбової діяльності як важливої складової ставлення молодших школярів до навчання. Науковий вісник Мелітопольського державного педагогічного університету. Сер. Педагогіка. 2008. С. 254-262. 
teaching, and the complication of the structure of the motivational field, the motivations that belong to it, the appearances of new, more mature, sometimes contradictory relations between them"12.

The motives of learning, and hence the direction of the personality, are specified by the content of learning, its significance. The content of teaching is understood the internal attitude to this type of activity, the constant comparison of learning with own experience of human, with oneself ${ }^{13}$.

The following main groups are allocated in the classification of motives for learning:

- the motives that are laid down in the educational activity:

- educational and cognitive motives that are related to the content of educational activity, which encourage students in a practical lesson of foreign language to find out new facts, to master not only theoretical knowledge and generalized ways of action, to penetrate into the essence of phenomena;

- learning motives that are related to the process of learning, which encourage the identification of intellectual activity, overcoming obstacles in the process of solving the tasks that have been set by the teacher.

- the motives that are related to what lies outside the educational activity:

- social motives that are related to both formal and informal student status in the academic group and reflect the social significance of learning. Among the social motives there is a subgroup of communicative motives (that are related to the effort of personality to establish himself in the team): self-improvement, self-education, readiness to fight for the honor of the group to compete for the depth of knowledge on a favorite subject, the motive of social prestige, the motive of social identification, the motive of communication, etc.

- professional (reflect the significance of learning activity for mastering the future profession);

${ }^{12}$ Степанченко Н. Особливості професійно-педагогічної мотивації майбутнього спортивного педагога. Фізичне виховання, спорт і культура здоров'я у сучасному суспільстві : збірник наукових праць. 2012. № 3 (19). С. 101-105.

${ }^{13}$ Васильев В. Л. Юридическая психология. Москва : Юрид. лит., 1991. 464 с. 
- motives for self-determination (understanding the significance of knowledge for the future profession and constant self-improvement in this direction);

- utilitarian (personal benefit, prosperity after graduation higher education institution);

- narrow personal motives: the desire to gain approval and positive evaluations (motivation for prosperity); the desire to be a leader and take a worthy place in the group (prestigious motivation);

- negative motives (motives that for their stimulation guide the teacher to use stimuli that are accompanied by negative emotions) that impede to learning:

- the desire to avoid annoyances from teachers, parents (motivation to prevent annoyances);

- the volatility - the motives are quickly satisfied, and without the support of the teacher may fade and not recover;

- weak generalization, i.e. cover one or more subjects that are united by external features;

- the focusing of students most often on result of learning, rather than on ways of learning activity, as a result, sometimes by the end of training in an institution of higher education there is no interest in overcoming difficulties in educational work ${ }^{14}$.

All these features cause a superficial, in some cases insufficient interest in teaching; it is sometimes called a formal and carefree attitude to the learning process itself. Therefore, the teacher must determine which types of motivation are more priority for the student and focus their attention on these types in the process of teaching a foreign language for the professional training. Speaking about the motives of learning activity, we usually mean the motives of the first group, which are substantially close to the learning activity itself.

Quite a large number of classifications of educational motives are built on the principle of their division into internal and external motives.

14 Попенко Т.В., Васеньова Ю.О. Проблеми мотивації до навчання в умовах сучасного стану ринку праці. Інформаційні технології в освіті, науці та виробництві. 2015. Вип. 4(11). С. 158-163. 
G.G. Bugrymenko ${ }^{15}$ detected the connection of internal learning motivation with the cognitive component of the image of "I". This connection is manifested in the fact that students with a more complex, "subtle" image of "I", who realize in detail their differences from significant others, are characterized by a higher level of the internal learning motivation.

It is defined in the research of psychological and pedagogical features of motives of learning activity of students of different higher education institutions of O.O. Chadenkova that motives of learning activity as a psychological phenomenon can change spontaneously and purposefully, but most often depend on the age and gender, intellectual and personal characteristics of students, as well as on the professional direction of the higher education institution. Students of technical higher education institutions on average have a higher level of development of motives of learning activities. The allocation of the leading motives of learning activity, which differ significantly in boys and girls, can occur in the process of entering of the student to learning activity in the higher education institutions. Girls are more prone to value factors, boys are more prone to factors of self-regulation. O.B. Zbanatska established ${ }^{16}$ that the basis of individual styles of learning activity of students with high academic performance are certainly personal characteristics, namely: methodical and intellectual flexibility of learning of training information; internality; high level of interaction of the personality, consistency, regularity of planning and implementation of learning actions. At the same time, the forming of style of learning is influenced by a high level of cognitive motivation, the motivation to achieve and focus on the final result.

${ }^{15}$ Бугрименко А. Г. Соотношение образа «Я» и внутренней учебной мотивации студентов: автореф. дисс. канд. психол. наук : спец. 19.00.07 «Педагогичская психология». Москва, 2007. 24 с.

16 Запорожан В. М., Нікогосян Л. Р., Аймедов К. В. Взаємозв'язок мотивації досягнень та успіхів у навчанні у студентів медичного факультету. Медична освіта. 2011. № 2. C. 108-113. 
It is shown in the researches of S.I. Kuchmieva ${ }^{17}$ that the process of professional training is positively influenced by motives that are based on interest in the profession, motives of personality development and educational and cognitive motives, is negative influenced by prosocial and infantile motives. Groups of material and social motives can have both positive and negative influence.

P. Ilyin ${ }^{18}$ provides a classification of P.M. Jacobson, who identifies several types of motivation that are associated with results of learning:

1) the motivation, which can be conditionally defined as "negative"; the motivations of a schoolboy or student that are caused by the awareness of certain inconveniences and troubles that may arise if he does not study (reproaches from parents, teachers, classmates). Such motivation does not lead to successful results of learning;

2) the motivation, which has a "positive" character, but is also associated with motives that are formed in not the activity itself. This motivation acts in two forms. In one case, such a positive motivation is determined by weighty social aspirations (sense of duty to nearest). Another form of motivation is determined by narrow personal motives: approval from surrounding, ways to achieve personal prosperity;

3 ) the motivation, which is the basis of learning activity (motivation that is directly related to goals of learning, curiosity satisfaction of overcoming obstacles, intellectual activity).

The concepts of "learning motivation" and "professional motivation" are divided in the psychological and pedagogical literature regarding the motivation of learning of students. On the one hand, the motivation of learning activity of students cannot be assimilated to school learning motivation, because has a professional direction to it has been already laid. On the other hand, the professional motivation of students does not yet correspond to the professional motivation of specialists, who are involved in professional activity.

There are three points of view regarding the effectiveness of learning activity of students, which is regulated by cognitive and professional

${ }^{17}$ Кучмиева С. И. Мотивационные факторы профессиональной социализации студентов в период обучения в ВУЗе. Автореф. дис... канд. социол. наук. Волгоград, 2007. 24 с.

${ }^{18}$ Ильин Э.П. Психология для педагогов. Питер, 2012. 638 с. 
motives: 1) the dominance of professional motives, which are external to the educational process, leads to a decrease of results in the cognition; 2) professional motives in comparison with cognitive more intensively influence efficiency of learning activity of students, therefore, it is desirable that professional motives be leading in the hierarchy of motives of students; 3) cognitive and professional motives in the learning activity of students is closely related to each other and increase its productivity ${ }^{19}$.

O.L. Afanasenkova, studying changes in motivation of students in the process of studying in higher education institutions, concluded that motivational readiness of students is a condition for success of professional activity, and the difference in the motives of students is determined by a number of factors, among which, first of all, the author provides the direction of professional training of students of institution of higher education, the leading strategy of behavior in educational and professional activity, the dominant internal or external motivation ${ }^{20}$.

Scientists identify certain techniques of motivation: belief; causing interest; suggestion; delegation; consolidating a positive impression.

Thus, there are present both internal motives of learning activity, and motives, which are external in relation to learning activity in the system of educational motives of students. One of the main tasks of university teaching is the increasing of the specific gravity of internal motivation, which is substantively close to learning activity, in the structure of motives of student. A.K. Markova considers that the internal attitude to learning contains two components:

- the awareness of the objective significance of learning, which is due to the system of ideals and values that are accepted in the society, social environment and family of the student;

- the awareness of the significance for the subject of the specified activity, which is closely related to the level of demands of the student, his self-esteem, self-control and opportunities ${ }^{21}$.

19 Єрохін, С. А. Концепція професійної мотивації студентів як фактору конкурентності на ринку праці. Юридична наука. 2011. № 1. С. 20-28.

20 Буяло Ю.В. Особливості ціннісно-мотиваційної сфери у студентів 3 різним проявом репресивного стилю поведінки. Вісник Харківського національного університету. Сер. Психологія. 2013. № 1065. С. 12-15.

${ }^{21}$ Васильев В. Л. Юридическая психология. Москва : Юрид. лит., 1991. 464 с. 
It is shown in the research of S.I. Kuchmieva that the process of professional training is positive influenced by motives that are based on interest in the profession, motives of development of personality and cognitive motives; is negative influenced by prosocial and infantile motives. It should be noted that the groups of material and social motives have both positive and negative nature, and the insufficient level of professional training of graduates of institutions of higher education is largely determined by the relatively low level of professional motivation of the students ${ }^{22}$. Today there is a significant amount of empirical data regarding the dynamics of professional, cognitive motivation, which reflect the change of leading motives at different stages of learning in the institutions of higher education.

Thus, motives become a condition for the forming of learning activity of students, when they meet the following requirements:

- the structure of motives is dominated by internal motivation, which is meaningfully related to learning activity;

- learning motives are deeply conscious and stable (power of motive);

- learning motives really work, are actualized in behavior, in learning actions $^{23}$.

Almost everything that the teacher does in the auditorium during the practical lesson has a motivating influence on students. The motivation of learning of students is largely determined by the development of their learning activity in the process of professional training. An important criterion for the study and development of motivation of teaching is the feeling as an indicator of how it is in the process of satisfying cognitive needs. Arising in the process of joint activity "teacher-student", positive emotional states indicate the favorable being in the process of meeting the needs.

Prominent educators believe that a true teacher must first have a thorough knowledge of the subjects that he teaches, love kids, know their

\footnotetext{
${ }^{22}$ Кучмиева С. И. Мотивационные факторы профессиональной социализации студентов в период обучения в ВУЗе. Автореф. дис... канд. социол. наук. Волгоград, 2007. $24 \mathrm{c}$.

${ }^{23}$ Дубасенюк О. А. Професійна підготовка майбутнього вчителя до педагогічної діяльності : монографія. Житомир : Житомир. держ. пед. ун-т, 2003. 193 с.
} 
age features, take them into account in his work, teach in the way to awaken the desire for knowledge in students. Interested in his subjects, with a creative approach to their teaching, wide awareness and erudition, teacher influences students by his own example. The forming of fullfledged motives for learning activity largely depends on the relations between the teacher and student, which are governed by the pedagogical tact of the teacher. Nothing in the work of the teacher should cause the student doubts and prejudices ${ }^{24}$.

A true teacher must convince them of his sincerity, kindness and justice with every word and action. In turn, when students are asked what do they like about their favorite teachers, such personality traits as sensitivity, cordiality, attention to requests and their own interests are emphasized in addition to these skills and knowledge. Only under these conditions, it is possible to bring up positive motives to study, as to responsible, interesting cooperation. The behavior of the teacher, his moral face, all these are important factors in educating a positive motive of teaching.

A number of didactic conditions for providing sustainable professional motivation for students has been offered in the scientific literature: professionalism of teacher; attitude to the student as a competent personality; promoting self-determination of student; organization of learning as a process of cognition; use of methods of stimulation of educational and cognitive activity; awareness of the coming and ultimate goals of learning; professional direction of learning activity; accessibility of content of educational material; forming (and maintenance) of aspirations of students to discover and assert themselves through educational and professional activity ${ }^{25}$.

I.M. Tolmachova complements this group of pedagogical conditions by the following: taking into account the dominant motives of learning of students depending on the year of study; organization of subject-subject interaction of the teacher and future teachers of primary classes; problem of the content of educational classes; involving students in the creation

\footnotetext{
24 Занюк С.С. Мотивація та саморегуляція учня. Київ: Главник, 2004. 96 с.

25 Єрохін, С. А. Конце.?пція професійної мотивації студентів як фактору конкурентності на ринку праці. Юридична наука. 2011. № 1. С. 20-28.
} 
and use of special educational products that are related to their mastery of pedagogy $\mathrm{y}^{26}$.

The most productive are internal motives that reflect the personal level of regulation of learning activity (self-regulation), and professional motives, which play the role of creating a relationship between learning activity and future professional activity.

Thus, the effectiveness of learning activity of students is higher in such cases where their efforts are determined by the internal motivational dominant. Numerous studies have proved that the leading motives of educational and professional activity of students are: the interest in learning, the need in personal self-realization, the attitude and professional recognition by teachers and classmates, the satisfaction with the organization of learning, the opportunity to manage the process of their learning activity by themselves, to show their own initiative, the need to feel their necessity for the group, to focus on their learning and their problems, the satisfaction with a favorable psychological climate in the group. An important role is played by the objectivity of assessment of knowledge; it is the compliance of ideas of students about social justice in the assessment of their efforts and learning.

\section{Level of professional motivation of future specialists in social work and the conditions of its forming}

Modern globalization and integration processes of development of Ukrainian society are changing the worldview and conceptual requirements for modern specialists, including specialists of social field. As a result, social workers face new requirements: to their knowledge, skills, personal qualities, which must have a modern specialist. The main task of modern higher education in Ukraine is the creation of such a model of learning and education, which will be focused on the development of the personality of future specialists throughout life.

Professional education in the social field is designed to meet the needs, interests, demands of each student regarding their own self-

26 Толмачова I. М. Формування професійної мотивації у майбутніх учителів початкових класів у процесі вивчення педагогіки. Молодий вчений. 2015. № 11 (26). Ч. 3. C. 64-67. 
realization, self-affirmation, as well as to further plans to work in various fields of social work. Expansion of the field of professional activity of a social work specialist, intensity of social changes, reforming the system of providing social services, introduction of new social and professional standards and values put conceptually new requirements for the personality of specialist in social work. Therefore, the task of the university system of education, we see in the organization of such conditions, which would stimulate the motivation of the professional activity of the future specialist in social work and included specific pedagogical interactions, primarily of didactic plan with an emphasis on a contextual approach. The implementation of this approach is to integrate the pedagogical and professional integral component of the content of training and determines, from our point of view, the effective forming of motivation in students to master the profession ${ }^{27}$.

Since, as scientists contend, the content of motivation of future specialists in social work is professional motivation; recognizability; pragmatism (satisfaction of material needs); motive of personal prestige. We have conducted research on identification of the level of forming professional motivation of students. 48 students of specialty "Social Work", including 22 3rd year and 26 4th year full-time students of Lesya Ukrainka Volyn National University took part in the research during the 2nd semester of 2020.

Analysis of research regarding the definition and classification of professional qualities of a social educator, allowed concluding that the profession of a specialist in social work should be mastered by people with special personal qualities. Thus, according to G.L. Efremov, the qualities that characterize the theoretical knowledge of a specialist in social work are: high level of intelligence against the background of a positive physical and mental state, high level of general culture, high level of motivation of the profession, competence ${ }^{28}$.

\footnotetext{
${ }^{27}$ Коваль Л. В. Професійна підготовка майбутніх учителів початкової школи: технологічна складова. Монографія. Донецьк : Юго-Восток, 2009. 375 с.

${ }^{28}$ Кочарян О. С., Фролова Є. В., Павленко В. М. Структура мотивації навчальної діяльності студентів. Навч. посіб. Харків : Нац. аерокосм. ун-т ім. М. Є. Жуковського «Харк. авіац. ін-т», 2011. 40 с.
} 
The experimental research was based on the use of four methods: Questionnaire "Attitude to the profession of social educator", "Motives for learning", "Method of diagnosing personality for motivation to succeed", "Method of motivation of education in the university" (T.N. Ilyina).

The level of formation of the value attitude to the activity of a specialist in social work was determined by means of a questionnaire: respondents were suggested to answer the question "Why do you study at the institution of higher education?". The table with the list of motives was offered, it is possible to choose only two motives.

According to the data of Table 1,27,2\% of 3rd and 23,1\% of 4th year students chose the desire to receive higher education. 59,1\% of third-year students and $42,3 \%$ of fourth-year students like their profession. This motive takes first place. 22,7\% of third-year students and $29,9 \%$ of fourth-year students want to be a good specialist; $31,8 \%$ of third-year students and $34,6 \%$ of fourth-year students want to be a cultured, educated person, $13,6 \%$ and $23,1 \%$ of students like to work with people.

Table 1

Attitude to the profession of specialist in social work

\begin{tabular}{|c|c|c|c|c|c|}
\hline \multirow{2}{*}{$\begin{array}{c}\text { No } \\
\text { S/n }\end{array}$} & Motive & \multicolumn{2}{|c|}{$\mathbf{3 3}$} & \multicolumn{2}{|c|}{$\mathbf{4 3}$} \\
\cline { 3 - 6 } 1 & $\mathbf{N}$ & $\mathbf{P}$ & 6 & $\mathbf{P}$ \\
\hline 2 & $\begin{array}{c}\text { To receive higher } \\
\text { education }\end{array}$ & 6 & 27,2 & 11 & 42,3 \\
\hline 3 & Like profession & 13 & 59,1 & 7 & 29,9 \\
\hline 4 & $\begin{array}{c}\text { Desire to be a good } \\
\text { specialist }\end{array}$ & 5 & 22,7 & 8 & 30,7 \\
\hline 5 & To be useful to people & 4 & 18,2 & 9 & 34,6 \\
\hline 6 & Like to we a cultured, educated \\
person & 7 & 31,8 & 6 & 23,1 \\
\hline 7 & Family traditions & 1 & 4,5 & - & - \\
\hline 8 & $\begin{array}{c}\text { State institution of higher } \\
\text { education }\end{array}$ & 4 & 18,2 & 3 & 11,5 \\
\hline 9 & Other priorities & 1 & 4,5 & 2 & 7,7 \\
\hline
\end{tabular}

State institution of higher education attracts 18,2\% of third and 11,5\% of fourth year students. Family traditions are inherent in $4,5 \%$ of third- 
year students, which corresponds to 1 student, and family traditions are not inherent in fourth-year students.

The questionnaire that was suggested to students had been compiled by us in order to determine the main types of motives and to find out which motives for learning predominate in students: internal or external. The analysis of the results demonstrates that the main motives of learning activity of students are the following answers "Knowledge, skills and abilities that have been acquired in an educational institution will be needed in life" $(83,3 \%)$, "Learning gives me certain advantages over peers, who work" $(77,1 \%)$,"Education is necessary to master the chosen profession" (83,3\%),"I want to become a good specialist" $(72,9 \%)$, "Good education is the basis for a successful career" $(66,6 \%)-$ these are the internal motives of a student that motivate him to successful professional activity, however, a fairly large number of students are guided by external motives, which negatively affect the forming of professional motivation, namely: "I think that the certificate (diploma) will give me some advantages in life over those who do not have it" $(87,5 \%)$, "Those, who are forced to learn by adults" $(85,4 \%)$. Thus, a large percentage of students who are guided by internal and external motives indicate instability, lack of professional motivation of students of specialty "Social work" to successful professional activity.

"Method of diagnosing personality for motivation to success" predicts 41 statements, to which the recipient must give one of 2 variants of answers: "yes" or "no". The test is related to monoscale methods. The number of points that are identical with key assesses the level of expression of motivation to success (Table 2).

Table. 2

Motivation to success

\begin{tabular}{|c|c|c|}
\hline Level & Number & Indicators, \% \\
\hline $\begin{array}{c}\text { Too high level of motivation } \\
\text { to success }\end{array}$ & 10 & 20,8 \\
\hline Moderately high level of motivation & 12 & 25 \\
\hline Medium level of motivation & 18 & 37,6 \\
\hline Low motivation to success & 8 & 16,6 \\
\hline
\end{tabular}


According to the results of the research, 8 students $(16,6 \%)$ have low motivation to success, 18 students $(37,6 \%)$ have medium level of motivation, 12 students ( $25 \%$ ) have moderately high level of motivation, 10 students $(20,8 \%)$ have too high level of motivation to success. The analysis of the results allows us concluding that most students have a low and medium level of motivation to success $(54,2 \%)$, they are indifferent to their successes, are not inclined to work hard and achieve more modest results in professional activity. However, 22 students, which represents $45,8 \%$, have a moderately high and too high level of motivation, which indicates that they study more faithfully, set high goals, work hard, striving to achieve the meaningful results. It should be mentioned that the high level of motivation of achievement encourages the student to search new information, development of own abilities and skills, in order to achievement of the set purposes both in learning, and in self-improvement. Accordingly, the development of motivation of achievement promotes activity, confidence in their opportunities and knowledge, forms a high overall self-esteem and confidence in their professional attractiveness.

Thus, the results that are obtained reveal a mostly low and medium level of forming professional motives in future specialists in social work, which indicates the lack of effectiveness of traditional forms and methods of the professional training of students.

The method of T.I. Ilyina regarding studying the motivation of learning at the higher education institution includes three scales:

1. "Acquisition of knowledge" (desire to acquire knowledge, curiosity);

2. "Mastering the profession" (the desire to master professional knowledge and form professionally important qualities);

3. "Receiving a diploma" (the desire to receive a diploma in the formal learning, the desire to search workarounds in exams and tests).

The results of the research will be presented for each scale for 3rd and 4 th year separately. Analysis of the data that are obtained by the method of T.I. Ilyina shows that $63,7 \%$ of 3 rd year students and $57,7 \%$ of 4th year students have a high and above medium motive of acquisition of knowledge, while $18,2 \%$ of 3 rd year students and $15,4 \%$ of 4 th year 
students have a low level, the medium level is typical of $18,2 \%$ of 3 rd year students and $26,9 \%$ of 4 th year students.

According to the results, the number of students with a high and medium level of motive to acquire knowledge increased at the 4th year, and the number of 4th year students with a low level decreased.

The results also show that the motive of learning by a scale "Mastering the profession" of high and above medium level is characterized for $40,9 \%$ of third-year students and $65,4 \%$ of fourth-year students, low level is characterized for $18,2 \%$ of third-year students and $11,5 \%$ of fourth-year students. However, a fairly large percentage of the medium level of motive to learning by a scale "Mastering the profession" is characterized for $40,9 \%$ of third-year students. This indicates a low need for third-year students to mastering the profession.

The results of the analysis of motives indicate a fairly high level of forming external motives of third and fourth year students, because the motive, which is by a scale "Receiving a diploma", is characterized at high and higher than medium levels for $59,1 \%$ of third-year students and $65,4 \%$ of fourth-year students.

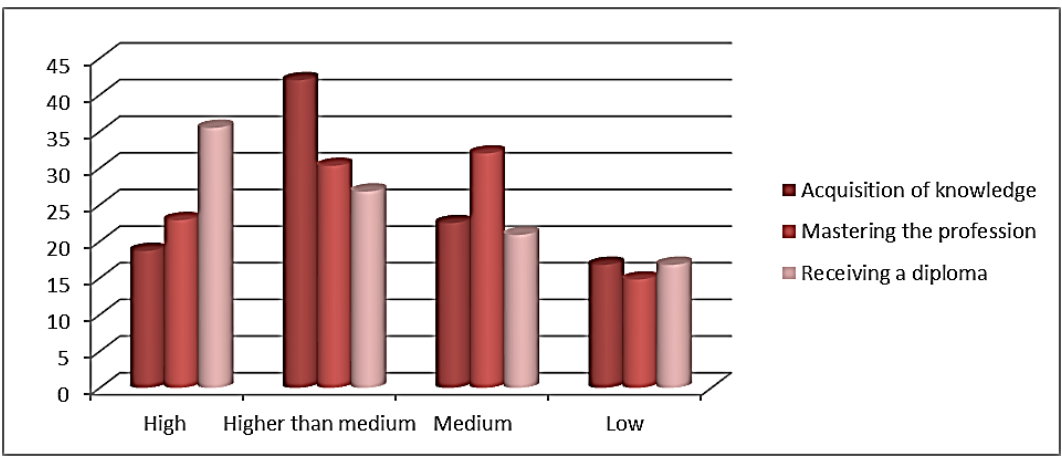

\section{Fig. 1. The level of motivation of learning in the higher education institution of students in the specialty "Social work"}

As it can be seen from Figure 1, the motive of receiving a diploma and the motive of mastering the profession are inherent in approximately the same number of students, this confirms the results of the method of 
Questionnaire "Motives of learning", namely, internal and external motives to the learning of students in the specialty "Social work" are at the same level.

Thus, the experimental research showed that traditional methods and forms of educational activities of higher education institutions do not provide the forming of their professional motives to successful professional activity in future social workers at a high level. According to the results of diagnostics of the level of formation of professional motivation of students, an insufficient level of its formation was revealed, because internal motives are not leading during learning, which can cause a low level of personal and professional self-realization of a social worker as a specialist of social field, who is capable to providing social services.

The conducted structural and functional analysis of the process of forming professional motivation of students-future specialists in social work allows determining the following organizational and pedagogical conditions of the educational process of training specialists in social work to providing social services:

1) Forming, support and stimulation of aspirations of students to discover and establish themselves through educational professional activity; in this regard it is possible to offer:

- detailed acquaintance with the future professional activity, its social significance, and with modern requirements to knowledge, abilities, skills and qualities of the personality of the specialist at learning all courses of disciplines;

- creating for the student the ideas about the modern model of the personality of a successful specialist and encouraging him to the short and long term perspective of professional self-realization;

- development of a positive concept of "I-concept" and adequate and sustainable self-esteem of the student as a subject of professional activity;

- forming a hierarchy of value orientations that are related to professional activity;

- developing for students the needs and skills to work independently with different sources of information, master information technologies and creatively apply knowledge in practice; 
- providing conditions for self-knowledge, self-education, to stimulate the desire for self-improvement;

- maintaining curiosity and "cognitive" psychological climate in the student academic group.

As a result, the student forms a vital temporary perspective, selfidentification with a successful professional, attitude to himself as a responsible performer of professional activity.

2) Minimization of high personal and situational anxiety of individual students, their uncertainty regarding future professional activity, by intensifying the development of professional qualities, abilities for selfregulation;

3) Creation of situations of success for students at a high level of realization of abilities, but not at the level of reduction of requirements and demands. Learning acquires a vital meaning if it brings satisfaction, experience of success, awareness of one's personal growth.

4) Subordination of the process of forming a high level of motivation to professional achievement to the following criteria in students:

- successful learning at the optimal level of complexity, which is determined by the requirements of the training course, as well as by the opportunities of the zone of current and closest development of each student;

- individualization of learning process;

- objectivity of pedagogical and moral assessments as an indicator of the personal achievements of student, rather than a means of his encouraging or punishing;

- introduction of dual education ${ }^{29}$.

We suggest the thought of scientists I.V. Nikitin and V.V. Martych about that, in our opinion, it is necessary for forming motivation of success in the professional activity in the social aspect:

1. To conduct selective disciplines to the curriculum at the second year of study at the higher education institution. To establish the introduction of practical directed special courses with the opportunity for

29 Толмачова I. М. Формування професійної мотивації у майбутніх учителів початкових класів у процесі вивчення педагогіки. Молодий вчений. 2015. № 11 (26). Ч. 3. С. 64-67. 
students to choose disciplines by their choice, what will give the opportunity to form "soft skills".

2. To strengthen the practical direction of training of students by introduction of classes with analysis and solving current work situations, training of professional excellence, conduction of practical classes on the basis of practice, involving practitioners to conduction of classes in auditoriums.

3. To introduce modeling of the resolution of conflicts with social institutions and clients, solving issues of clients, assistance in receiving social services, business negotiations with clients, their training in elements of mediation, business games, etc. into the curriculum for undergrads.

4. To involve employers in the discussion of educational programs, curricula, selective disciplines.

5. To improve the system of passing production practices, to introduce inseparable from the educational process practice.

6. To unify the requirements of the labor market with the criteria of quality training of specialists.

7. Introduce conducting scientific and practical seminars on actual problems of professional activity with the participation of teaching staff of the higher education institution, scientists, students, specialists of the social field, law enforcement agencies, representatives of the department of education, the administration of facilities of general secondary and preschool education, etc.

Another condition of the development of motivation for students to the activity of a social worker is the update of the content and technologies of educational activity in the higher education institution with the including of the following components: didactic ensuring (content, methods of implementation, ways of interaction in the system "teacher-student"), which is based on the integration of pedagogical and social components of training on the basis of the contextual approach; professionally oriented tasks that update the life experience of students in connection with the specialty; participation in socially significant activity; psychological and pedagogical interaction on the development of motivation. 
The criteria that will form the system of professional motivation should become:

1. Address recognition of results of activity, satisfaction of need for personal involvement to results of work.

2. Success in achieving the goal to which the person has made an effort will contribute to increase interest in work in the future.

3. Achievable and mobilizing criteria for evaluating activity that are able to not raise pessimism and disbelief in their own strength.

4. Success especially that, which required additional effort, must be supported by material and moral incentives ${ }^{30}$.

\section{CONCLUSIONS}

The motivational component in the system of training future specialists in social work to providing social services is currently one of the leading, because it will be able to help the future specialist in social work to overcome possible shortcomings of theoretical and practical training, since motivation acts in its capacity as an internal factor of professional and personal progress, because only a very motivated person can succeed in professional and cultural self-development. Professional motivation acts in its capacity as an internal factor of professional and personal progress, because only a very motivated person can succeed in professional and cultural self-development. Motivation is a set of needs, relations, interests, satisfaction with learning activity and provides a good professional in the future.

The structural components of professional motivation are the motivation of initiation (encourages activity); motivation of selection (promotes the choice of goal); motivation of implementation (provides regulation, control over the implementation of the relevant action); motivation of post-realization (allows completing the actions and motivate to another).

30 Лисовец, Н.М. Профессиональная мотивация студентов как способ активации обучения. URL : http://www.masters.donntu.edu.ua/2012/iem/temnenko/library/ article5.htm. 
The motivational field of the student is characterized by the desire to learn for the sake of achieving not only academic goal, but also for professional growth, to do this, the student must want to actively participate in the process of learning. The level of learning activity of a student is a consequence of strong or weak motivation of learning.

The conducted structural and functional analysis of the process of forming professional motivation of students-future specialists in social work allows determining the following organizational and pedagogical conditions of the educational process of training specialists in social work to providing social services:

1) Forming, support and stimulation of aspirations of students to discover and assert themselves through educational and professional activity.

2) Minimization of high personal and situational anxiety of individual students, their uncertainty regarding future professional activity, by intensifying the development of professional qualities, abilities for selfregulation;

3) Creation of situations of success for students at a high level of realization of abilities, but not at the level of reduction of requirements and demands. Learning acquires a vital meaning if it brings satisfaction, experience of success, awareness of one's personal growth.

4) Subordination of the process of forming a high level of motivation to professional achievement to the following criteria in students: successful learning at the optimal level of complexity, which is determined by the requirements of the training course, as well as by the opportunities of the zone of current and closest development of each student; individualization of learning process; objectivity of pedagogical and moral assessments as an indicator of the personal achievements of student, rather than a means of his encouraging or punishing; introduction of dual education.

In addition, it is necessary to support all types of self-educational activity of students, push them to the activity, initiative and independence, the expanding of types and forms of independent search of professional knowledge that is to self-improvement. 


\section{SUMMARY}

The problem of compliance with the needs of the labor market and the possibility of training modern specialists in social work by higher education institutions has been mainstreamed in the article. In the current conditions of transformation of society, the institutions of higher education of Ukraine face a difficult, responsible task, which is highquality training of future specialists in the system of higher education for professional activity in specific conditions; providing labor market with qualified specialists; meeting educational needs of the student and helping him in awareness of his mission. For providing high-quality training of specialists in social work to providing social services, the cooperation of higher education institutions with institutions of social field, territorial communities. The effectiveness of professional activity depends on the study of the motivational field, since the motivation is the driving force of behavior of a human, what plays a significant role in professional self-determination, and is a necessary condition of the forming of individual style of activity, professionally significant qualities. The leading motives of educational and professional activity of students are: the interest in learning, the need in personal self-realization, the attitude and professional recognition by teachers and classmates, the satisfaction with the organization of learning, the opportunity to manage the process of their learning activity by themselves, to show their own initiative, the need to feel their necessity for the group, to focus on their learning and their problems, the satisfaction with a favorable psychological climate in the group.

The results of the research of the motivational sphere of students of the specialty "Social Work", an insufficient level of its formation was revealed, because internal motives are not leading during learning, which can cause a low level of personal and professional self-realization of a social worker as a specialist of social field, who is capable to providing social services. The organizational and pedagogical conditions of the educational process of training specialists of social work to providing social services have been developed and substantiated. 


\section{REFERENCES}

1. Бірюк О.О. Психологічні особливості професійної мотивації педагогічних працівників загальноосвітніх навчальних закладів нового типу : автореф. дис. на здобуття наук. ступеня канд. психол. наук : спеціальність 19.00.10 «Організаційна психологія; економічна психологія». Київ, 2012.

2. Бугрименко А. Г. Соотношение образа «Я» и внутренней учебной мотивации студентов: автореф. дисс. канд. психол. наук : спец. 19.00.07 «Педагогичская психология». Москва, 2007. 24 с.

3. Буяло Ю.В. Особливості ціннісно-мотиваційної сфери у студентів з різним проявом репресивного стилю поведінки. Вісник Харківського національного університету. Сер. Психологія. 2013. № 1065. C. 12-15.

4. Васильев В. Л. Юридическая психология. Москва : Юрид. лит., 1991. 464 с.

5. Гузь Н.В. Вивчення мотивів учбової діяльності як важливої складової ставлення молодших школярів до навчання. Науковий вісник Мелітопольського державного педагогічного університету. Сер. Педагогіка. 2008. С. 254-262.

6. Дубасенюк О. А. Професійна підготовка майбутнього вчителя до педагогічної діяльності : монографія. Житомир : Житомир. держ. пед. ун-т, 2003. 193 с.

7. Дусавицкий А.К. Мотивы учебной деятельности студентов. Учеб. пособие. Харьков: ХГУ, 1987. 55 с.

8. Єрохін, С. А. Концепція професійної мотивації студентів як фактору конкурентності на ринку праці. Юридична наука. 2011. №1. C. 20-28.

9. Занюк С.С. Мотивація та саморегуляція учня. Київ: Главник, 2004. $96 \mathrm{c}$.

10.Запорожан В. М., Нікогосян Л. Р., Аймедов К. В. Взаємозв'язок мотивації досягнень та успіхів у навчанні у студентів медичного факультету. Медична освіта. 2011. № 2. С. 108-113.

11. Ильин Э.П. Психология для педагогов. Питер, 2012. 638 с. 
12.Коваль Л. В. Професійна підготовка майбутніх учителів початкової школи: технологічна складова. Монографія. Донецьк : Юго-Восток, 2009. 375 с.

13.Кочарян О. С., Фролова Є. В., Павленко В. М. Структура мотивації навчальної діяльності студентів. Навч. посіб. Харків : Нац. аерокосм. ун-т ім. М. Є. Жуковського «Харк. авіац. ін-т», 2011. $40 \mathrm{c}$.

14.Кучмиева С. И. Мотивационные факторы профессиональной социализации студентов в период обучения в ВУЗе. Автореф. дис... канд. социол. наук. Волгоград, 2007. 24 с.

15.Лисовец, Н.M. Профессиональная мотивация студентов как способ активации обучения. URL : http://www.masters.donntu.edu.ua/2012/iem/temnenko/library/ article5.htm.

16. Ляшенко І.В. Формування професійної мотивації студентів до успішної фахової діяльності. URL : www.narodnaosvita.kiev.ua/ ?page_id=1076

17.Попенко Т.В., Васеньова Ю.О. Проблеми мотивації до навчання в умовах сучасного стану ринку праці. Інформаційні технології в освіті, науцуі та виробництві. 2015. Вип. 4(11). C. 158-163.

18.Слозанська, Г.І. Теорія і практика професійної підготовки майбутніх соціальних працівників до роботи у територіальних громадах. Дис. на здобуття наук. ступеня д-ра пед. наук. 13.00.05. Тернопіль. 2019. 687 с.

19. Слозанська, Г. I. Взаємозв'язок професійної підготовки студентів спеціальності «соціальна робота» у ВНЗ з можливістю їхнього працевлаштування. Науковий вісник Ужгородського національного університету. Сер: Педагогіка. Соціальна робота. Ужгород, 2016. № 39. С. 236-240.

20.Степанченко Н. Особливості професійно-педагогічної мотивації майбутнього спортивного педагога. Фізичне виховання, спорт $i$ культура здоров'я у сучасному суспільстві : збірник наукових пращь. 2012. № 3 (19). С. 101-105. 
21. Толмачова I. М. Формування професійної мотивації у майбутніх учителів початкових класів у процесі вивчення педагогіки. Молодий вчений. 2015. № 11 (26). Ч. 3. С. 64-67.

22.Хорошайло Ю. Є. Особливості професійної мотивації та іï врахування в роботі з персоналом. Актуальні проблеми соціальної, психологічної та виховної роботи в ОВС: Матеріали науковопрактичної конферениії (Харків, 30 жовтня 2008 року). Харків : ХНУВС, 2008. С. 3-4.

\section{Information about the authors: Cherneta S. Yu.}

Candidate of Pedagogical Sciences, Associate Professor, Head of the Department of Social Work and Pedagogy of the Higher School, Lesya Ukrainka Volyn National University 13 Voli ave., Lutsk, Volyn region, 43025, Ukraine

Sushyk N. S.

Candidate of Pedagogical Sciences, Associate Professor, Associate Professor at the Department of Social Work and Pedagogy of the Higher School

Lesya Ukrainka Volyn National University 13 Voli ave., Lutsk, Volyn region, 43025, Ukraine 